Acta Universitatis Nicolai Copernici • Pedagogika XXVIII/2012

Nauki Humanistyczno-Społeczne • Zeszyt 405

Marzenna Zaorska

Uniwersytet Mikołaja Kopernika w Toruniu

\title{
ROZWÓJ KULTUROWY DZIECKA W KONCEPCJI LWA S. WYGOTSKIEGO
}

Jiniejszy tekst, poświęcony analizie problematyki rozwoju kulturodrzejowi Wojciechowskiemu, prof. UMK - wspaniałemu człowiekowi, niepowtarzalnemu, ciepłemu, otwartemu na ludzi, szczególnie ludzi potrzebujących pomocy, wsparcia, zrozumienia ich niedoskonałości, a często również inności i stygmatu bycia innym. Profesor Andrzej Wojciechowski jest nie tylko zasłużonym i wieloletnim pracownikiem Uniwersytetu Mikołaja Kopernika w Toruniu, Wydziału Nauk Pedagogicznych (wcześniej Instytutu Pedagogiki Wydziału Humanistycznego), Katedry Pedagogiki Specjalnej (wcześniej Zakładu Pedagogiki Specjalnej), ale też współorganizatorem Katedry Pedagogiki Specjalnej, a przedtem Zakładu Pedagogiki Specjalnej (przez długi czas Pan Profesor był jego Kierownikiem), Osobą i Osobowością znaną w naszym kraju i za granicą z uwagi na wybitne i niepodważalne osiągnięcia w obszarze terapii przez sztukę ludzi doświadczających konsekwencji stanu niepełnosprawności, przede wszystkim konsekwencji stanu niepełnosprawności intelektualnej oraz wielowymiarowej aktywizacji tych ludzi ukierunkowanej na otoczenie i siebie samych celem uzyskiwania autonomii osobowej i społecznej. 


\section{ROZWÓJ KULTUROWY DZIECKA W KONCEPCJI LWA S. WYgOTSKIEgo*}

Zdaniem L. S. Wygotskiego w procesie rozwojowym dziecko nie tylko opanowuje doświadczenie kulturowe zdobyte i wypracowane przez pokolenia minione, ale także powszechnie przyjęte formy zachowań społecznych w obszarze aktywności kulturowej oraz sposoby kulturalnego myślenia i sposoby myślenia o kulturze. Sugeruje, że proces rozwoju kulturowego dziecka należy analizować, interpretować i oceniać w dwóch podstawowych płaszczyznach, a właściwie ukierunkowaniach, nazywanych przez L. S. Wygotskiego liniami/drogami. Pierwsza z nich obejmuje specyfikę rozwoju naturalnego, indywidualnego, który jest determinowany istniejącymi możliwościami i predyspozycjami organizmu człowieka, tzn. jest warunkowana czynnikami biologicznymi. Druga - to zdobywanie doświadczeń społecznych/kulturalnych poprzez relacje z innymi ludźmi; stanowi podstawę rozwoju istotnych funkcji psychicznych, funkcji intelektualnych, nabycia kulturowych zachowań i operowania zachowaniami/czynnościami powszechnie postrzeganymi jako mieszczące się w działalności/aktywności kulturowej ${ }^{1}$.

Dziecko starsze, zauważa L. S. Wygotski, ma większe możliwości zapamiętywania z uwagi na to, że proces/procesy zapamiętywania u dziecka starszego funkcjonują w sposób bardziej celowy i doskonały oraz są w większym stopniu utrwalone w porównaniu z dzieckiem młodszym. Jednak poznanie, po której w podanych wyżej linii/dróg rozwój kulturowy dziecka przebiega/przebiegał, z jaką intensywnością i ewentualną specyfiką, wymaga specjalistycznych badań, szczególnie badań psychologicznych. Dziecko może bowiem zapamiętywać

Wszystkie treści ujęte $\mathrm{w}$ niniejszym tekście zostały przygotowane na podstawie następującego opracowania: L. S. Wygotski, Zagadnienie rozwoju kulturowego dziecka, w: L. S. Wygotski, Psychologia rozwoju człowieka, Wydawnictwo Smysł, Moskwa 2003, s. 191-207 (Л. С. Выготский, Проблема культурного развития ребёнка. В: Л. С. Выготский, Психология развития человека, Издательство Смысл, Москва 2003, с. 191-207).

1 Tamże. 
lepiej, łatwiej i bardziej efektywnie, ponieważ dysponuje znakomitymi możliwościami wewnętrznymi, przede wszystkim w zakresie funkcjonowania procesów neurobiologicznych, stanowiących biologiczne uwarunkowanie rozwoju pamięci, co oznacza, że dysponuje znakomitą biologiczną podstawą rozwoju pamięci. Jednakże rozwój pamięci może/mógł podążać zupełnie inną drogą, co sugeruje, że funkcjonowanie pamięci nie uległo wyraźnemu oraz zauważalnemu rozwojowi, pozostaje mniej więcej na zbliżonym poziomie, ale dzięki sobie i otoczeniu dziecko zdobyło umiejętności operowania własną pamięcią, poznało sposoby lepszego i efektywniejszego zapamiętywania i potrafi je wykorzystać, jeśli zachodzi taka potrzeba, np. za pomocą specjalnych ćwiczeń, stosowania skojarzeń lub wybranych symboli/znaków ułatwiających zapamiętywanie. Na ogół jednak, zdaniem L. S. Wygotskiego, w procesie rozwoju pamięci uruchamiane są dwie z podanych dróg aktywizacji oraz doskonalenia tej funkcji psychicznej. Dlatego dziecko starsze nie tylko zapamiętuje efektywniej, szybciej, więcej i łatwiej, ale też inaczej, tzn. z inną specyfiką, w porównaniu z dzieckiem młodszym. W rozwoju bowiem dziecka zachodzi stała i jakościowo zróżnicowana zmiana jego zachowania oraz zastępowanie zachowań mniej doskonałych bardziej doskonałymi i bardziej charakteryzującymi się jakościowo wyższym poziomem rozwojowym ${ }^{2}$.

Przykładem rozwoju kulturowego dziecka w sferze pamięci jest zapamiętywanie, np. map geograficznych, planów czy schematów. W związku z powyższym, podkreśla L. S. Wygotski, istnieją realne podstawy, aby sądzić, że rozwój kulturowy polega na poznaniu i opanowaniu takich sposobów zachowania, jakich postawą są różnorodne symbole, które ułatwiają realizację określonej operacji psychicznej. Stąd rozwój kulturowy polega przede wszystkim na opanowaniu wspomagających kulturowe zachowania symboli wypracowanych przez ludzkość w procesie rozwoju historycznego i uznanych za powszechnie przyjęte, obowiązujące, porządne oraz zrozumiałe. Do takich symboli można zaliczyć język, pismo, cyfry i inne. Dowodów na potwierdzenie, że dane symbole są nośnikami rozwoju kulturowego dostarcza analiza zachowania ludzi pierwotnych oraz małych dzieci. Ponadto w psychologii istnieje określenie „dziecięcego prymitywizmu

2 Tamże. 
kulturowego" pojmowane jako przejawianie przez dziecko zachowań stosunkowo prymitywnych, w porównaniu z powszechnie przyjętymi, które może być warunkowane zarówno determinantami rozwojowymi (np. opóźnienie rozwoju), jak i środowiskowymi (wynikającymi z braku wzorców do naśladowania). Prymitywizm w rozwoju kulturowym charakteryzuje się więc przede wszystkim opóźnieniem tego rozwoju, powstającym na tle nieopanowania symboliki umożliwiającej ów rozwój, np. języka. Dziecko wykazujące prymitywizm w rozwoju kulturowym jest jednak de facto dzieckiem pełnosprawnym w rozwoju psychofizycznym i tym właśnie różni się od dziecka niepełnosprawnego intelektualnie, u którego prymitywizm kulturowy ma inne źródła i konteksty. Prymitywizm kulturowy dziecka niepełnosprawnego intelektualnie w ujęciu L. S. Wygotskiego rzutuje na opóźnienie rozwoju ogólnego i w dużym stopniu może ten rozwój determinować. Może także łączyć się bezpośrednio lub pośrednio z niepełnosprawnością intelektualną. Aczkolwiek istota niepełnosprawności intelektualnej i istota prymitywizmu kulturowego nie są tożsame, lecz mają różne uwarunkowania i różne konsekwencje. Czym innym bowiem jest stan niepełnosprawności intelektualnej wynikający z faktu uszkodzenia mózgu, a czym innym opóźnienie w rozwoju kulturowym spowodowane brakiem lub niewłaściwym opanowaniem środków i symboliki zachowań, identyfikowanych jako kulturowe, oraz kulturowego sposobu myślenia. Wygotski przytacza przykład 9-letniej, pełnosprawnej intelektualnie dziewczynki, której zdano kilka pytań:

1) w jednej ze szkół część dzieci doskonale opanowała umiejętność pisania, a część umiejętność rysowania - czy wszystkie dzieci w tej szkole doskonale opanowały umiejętności pisania i czytania? odpowiedź dziewczynki - nie wiem tego, czego nie widziałam na własne oczy i nie mogę wyjaśnić;

2) chłopiec ma zabawki wykonane wyłącznie z drewna, a rzeczy wykonane $\mathrm{z}$ drewna nie toną $\mathrm{w}$ wodzie - czy mogą zatonąć w wodzie zabawki tego chłopca? odpowiedź dziewczynki - nie, dlatego że drewno nie tonie w wodzie, a kamień tonie; sama widziałam na własne oczy;

3) wszyscy bracia pewnego człowieka mieszkają nad morzem i potrafią świetnie pływać - czy wszyscy ludzie mieszkający nad morzem potrafią pływać, czy nie? odpowiedź dziewczynki - część 
ludzi mieszkających nad morzem potrafi pływać, a część nie, widziałam to na własne oczy; mam cioteczną siostrę, która nie potrafi pływać;

4) przeważnie mężczyźni są wyżsi od kobiet - czy wyższy od swojej żony jest wujek pewnego człowieka? odpowiedź dziewczynki nie wiem, gdybym znała wujka tego człowieka, to odpowiedziałabym na pytanie, czy jest wyższy od swojej żony, czy nie;

5) pewien człowiek ma podwórko wokół swojego domu, które jest mniejsze od sadu, który to sad również znajduje się przy domu, a z kolei sad jest mniejszy od ogrodu wokół domu tego człowieka? - pytanie - czy podwórko jest mniejsze od sadu i ogrodu wokół domu tego człowieka? odpowiedź dziewczynki - nie wiem, przecież nie widziałam tego domu, dlatego nie mogę powiedzieć, czy podwórko jest większe od sadu i ogrodu ${ }^{3}$.

Inny przykład: chłopiec w normie intelektualnej został zapytany o to, jakie podobieństwo istnieje między drewnem a drzewem. Odpowiedź chłopca: nie wiem, nie mam pojęcia, nie widziałem drewna i drzewa; przy moim domu rośnie lipa i wiem, jak wygląda, ale nie mogę odpowiedzieć na to pytanie.

Opóźnienie w rozwoju kulturowym u opisanych dzieci wynika z opóźnienia w rozwoju logicznego myślenia oraz z opóźnienia w rozwoju mowy, szczególnie systemu leksykalnego. Rozwój myślenia i rozwój mowy są bowiem ze sobą ściśle powiązane i wzajemnie skorelowane. Ponadto opanowanie języka w sposób prymitywny bezpośrednio rzutuje na rozwoju myślenia i może ów rozwój opóźniać, a dodatkowo może opóźniać szczególnie istotnie te sfery rozwoju i te funkcje psychiczne, które są już opóźnione bardziej od innych.

W opisanym wyżej przykładzie dziewczynki, która - jak wyjaśnia L. S. Wygotski - zmieniła dotychczasowe środowisko językowe, na innych widać, że nie w pełni opanowała nowy język jako ważny środek myślenia w sytuacjach aktualnych i jako środek/stymulator rozwoju myślenia, chociaż $\mathrm{w}$ prostej formie go rozumie i potrafi się nim komunikować. Jednak nie rozumie znaczenia wielu pojęć, zasłania się brakiem bezpośredniej styczności z ich desygnatem. Oznacza to, że w cytowanym przypadku jednoznacznie dostrzegamy różnice między

3 Tamże. 
naturalną linią rozwoju kulturowego i linią determinowaną sytuacją środowiskową. Na ogół jednak te dwie linie przenikają się wzajemnie, wzajemnie warunkują i wpływają na rozwój jednej i drugiej .

Podane przykłady jasno dowodzą, że rozwój kulturowy nie tworzy niczego ponad lub dodatkowego, co nie byłoby obecne w programie rozwoju kulturowego dziecka. Kultura nie tworzy niczego ponad to, co jest dane ludziom przez ich naturę, ale zmienia i modyfikuje naturę ludzką poprzez podporządkowanie jej celom wyznaczanym przez ludzi. Identycznie rzecz się ma w rozwoju zachowania identyfikowanego jako kulturalne. Istotą tego rozwoju jest modyfikowanie zaprogramowanych przez naturę ludzką zachowań na zachowania przynależne ludziom. Bardziej skomplikowane zachowania włączają elementy obecne w mniej skomplikowanych formach zachowań. Ludzie w sposób celowy i ukierunkowany starają się modyfikować własne zachowania, jednak ich modyfikacja oraz granice owej modyfikacji warunkowane są naturą ludzką i mogą się zmieniać na tyle, na ile natura na to pozwoli. Oznacza to, że zachowania o wysokim stopniu złożoności łączą się, a nawet mogą być ograniczane przez zachowania o niskim poziome złożoności, wręcz prymitywne, ale mające naturalne źródła.

Każde zachowanie identyfikowane jako kulturowe, nawet to najbardziej skomplikowane, może być podzielone na konkretne elementy składowe na podstawie kryterium ich neurobiologicznych uwarunkować i naturalnych źródeł. Podobnie jak można dokonać podziału funkcjonowania bardzo skomplikowanego urządzenia na elementy składowe, bazując na istocie procesów fizyczno-chemicznych, zachodzących w pracy każdego z tych elementów. Stąd do zadań badań naukowych realizowanych w obszarze poznania zachowań kulturowych należy ich analiza poprzez rozłożenie na elementy składowe oraz poznanie istoty tych elementów w sensie określenia naturalnych i psychicznych procesów przyczyniających się do powstania konkretnego elementu, a zatem całego zachowania. Wskazane postępowanie naukowe zrealizowane w sposób rzetelny i prawdziwie obiektywny zawsze doprowadza do wniosku, że nie istnieje żadne skomplikowane zachowanie kulturowe i kulturowy sposób myślenia, które/który nie było/byłby zbudowane/ zbudowany z elementów składowych o mniej skomplikowanej postaci,

4 Tamże. 
a nawet nieco prymitywnym charakterze. Oto przykład wyjaśniający daną argumentację. Dziecko otrzymuje zadanie zapamiętania określonej liczby cyfr, słów lub określonej partii materiału. Kiedy zadanie, to nie wykracza ponad naturalne możliwości, dziecko wykona to zadanie, korzystając z naturalnych, a przez to prymitywnych wręcz sposobów jego realizacji. Zapamiętanie będzie odbywać się na podstawie czynności asocjacyjnych lub odruchów bezwarunkowych. Jednak życie na ogół stawia dziecku zadania przekraczające jego naturalne możliwości, które nie mogą być osiągnięte wyłącznie za pomocą mechanizmów asocjacyjnych lub stosujących odruchy bezwarunkowe. Na przykład przed dzieckiem znajdują się niezwiązane z naturalną zabawą materiały: papier, agrafki, sznurek, drobne kamyki i inne. Dziecko może zainteresować się sznurkiem i korzystając z doświadczenia, spróbować np. zawiązać pętelki na sznurku, przekłuć agrafką papier czy liczyć lub przekładać kamienie. Wykazuje więc zachowania kwalifikowane jako zachowania kulturowe, oparte na znaczeniu symboliki wpisanej w przedmioty znajdujące się przed dzieckiem. Realizuje więc określone zadania, które są wywołane za pomocą stymulacji zewnętrznej, ale za sposób i charakter ich realizacji odpowiadają wewnętrzne mechanizmy psychologiczne. I takie zachowania oraz przebieg wykonania określonych działań różnią dziecko od np. małp, które nie potrafią uruchomić mechanizmów wewnętrznych tak, by realizowane zachowania były adekwatne wobec istniejących i ogólnie przyjętych norm ${ }^{5}$.

Można więc konkludować, że rozwój pamięci u ludzi przebiegał na bazie symboliki i znaczenia znaków, które przypisała im ludzkość w czasie historyczno-kulturowego rozwoju, nadając zachowaniu człowieka charakter swoisty wyłącznie dla istot ludzkich. Sens naturalnej oraz kulturowej pamięci można - zdaniem L. S. Wygotskiego - przedstawić za pomocą trójkąta. W zapamiętywaniu naturalnym tworzy się nieskomplikowana asocjacja lub zachowanie na podłożu odruchów bezwarunkowych między punktem A i punktem B. W czasie zapamiętywania kulturowego wykorzystującego znaki/symbole zamiast prostego, asocjacyjnego połączenia pomiędzy punktem A i B tworzą się bardziej skomplikowane połączenia AX i BX, doprowadzające do identycznego rezultatu, ale odmienną drogą. Chociaż zarówno połączenie

5 Tamże. 
AX, jak i BX ma charakter naturalny, asocjatywny, uzależniony od procesów neurobiologicznych, jak połączenie AB. Oznacza to, że zachowanie powstające na zasadzie połączenia AX i BX można podzielić na identyczne elementy, jak zachowanie powstające na bazie połączenia AB. Novum w konstelacji AX i BX jest to, że obecne są zamiast jednego połączenia $\mathrm{AB}$, dwa - AX i BX. Także konstrukcja i kombinacja pojawiających się połączeń nerwowych oraz ukierunkowanie ich zamknięcia korzystające ze znaku/symbolu. Ponadto novum stanowi nie tyle struktura samego zachowania, ile przebieg procesu zapamiętywania zachowania kulturowego ${ }^{6}$.

Kolejnym zadaniem badań naukowych nad istotą zachowań kulturowych jest poznanie przebiegu procesu zapamiętywania zachowania kulturowego. Chociaż, jak już sugerowano wyżej, każde zachowanie kulturowe, w ujęciu L. S. Wygotskiego, składa się z naturalnych zachowań i pierwotnych procesów psychicznych, zachowanie kulturowe zaś oponowane za pomocą symboli zewnętrznych charakteryzuje się tym, że powstaje nie w sposób mechaniczny, a strukturalizowany celowo. Oznacza to, że budujące takie zachowanie elementy i procesy odznaczają się stosunkowo wysokim stopniem złożoności funkcjonalnej i realizacyjnej, który egzemplifikuje się w postaci zachowania realizowanego w formie zglobalizowanej i w sposób płynny poprzez skoordynowanie elementów owe zachowanie tworzących. Owa globalizacja zapamiętywania zachowań kulturowych wyraża się w charakterze konkretnego działania, którego celem jest jego realizacja, oraz w środkach, które będą wykorzystane w czasie jego realizacji i zapamiętywania zachowania. Szczególne znaczenie z punktu analizy zachowań kulturowych ma drugi ze wskazanych wyżej elementów, tj. środki, które będą wykorzystane w czasie realizacji konkretnego zachowania i jego zapamiętywania. Identyczne bowiem zachowania mogą być zrealizowane za pomocą różnych środków, co oznacza, że struktura realizowanego zachowania będzie odmienna $\mathrm{z}$ powodu różnorodności środków zastosowanych w czasie jego realizacji. Dziecko bowiem może skorzystać z pomocy mechanizmów wewnętrznych i już w tym momencie sposób wykonania określonego zachowania będzie inny. Oznacza to, że zapamiętywanie oparte na odmiennych symbolach i mechanizmach

6 Tamże. 
ma nietożsamą strukturę. Zróżnicowanie i odmienność powstają z przyczyny zastosowanego znaku służącego jego realizacji. Stąd znak jest epicentrum decydującym o nabywaniu i zapamiętywaniu zachowań kulturowych. Rzutuje też na ich strukturę, przebieg oraz istotę. Włączenie $\mathrm{w}$ proces zapamiętywania zachowań kulturowych jakiegokolwiek znaku, którego obecność sprzyja zapamiętywaniu i realizacji zachowania, powoduje też zmianę reakcji psychicznych, a powstające $\mathrm{w}$ tym procesie reakcje mają swoisty charakter. Identycznie rzecz się ma z włączeniem w czynności wykonywane na określonym stanowisku pracy przedmiotu wspierającego te czynności (np. w celu wytarcia podłogi zamiast klasycznej szmaty/ścierki wykorzystywany jest mop). Reasumując - na przebieg oraz charakter zapamiętywania zachowań kulturowych rzutują stosowane środki, które budują specyfikę przebiegu procesu zapamiętywania, chociaż mimo różnorodności środków końcowy rezultat realizowanego zachowania może być identyczny. W czasie zapamiętywania naturalnego korzystanie z asocjacji, porównań, domysłu powoduje aktywizację już obecnych w pamięci zasobów, które mogą zostać wykorzystane w celu zapamiętania nowych zachowań kulturowych. Procesy psychiczne służą więc nieocenioną pomocą w przyswajaniu nowych zachowań i regulują zachowanie ludzi w globalnej postaci, bez względu na obecność zachowań już znanych czy zachowań dotąd niespotykanych ${ }^{7}$.

Struktura nabywania zachowań kulturowych przez dziecko jest zmienna. Nie powstaje $\mathrm{z}$ niczego - powstaje naturalnie $\mathrm{w}$ określonym czasie w przebiegu rozwoju dziecka. Nie może też być narzucona dziecku siłowo. Pojawia się jako pewna prawidłowość warunkowana wewnętrznie, chociaż zasadniczo rozwija się i kształtuje pod wpływem czynników zewnętrznych. Kiedy się jednak pojawi, to nie pozostaje stabilna, a podlega wielorakim i długotrwałym zmianom. Każde nowe zachowanie kulturowe nie pozostaje niezmienne i w stu procentach utrwalone jako nabyta wewnętrznie umiejętność. Mimo że ma swoją własną, indywidualną historię, stanowi element ogólnej charakterystyki zachowania dziecka i daje podstawy, by sądzić, że ogólne zachowanie kulturowe i kulturowe myślenie składa się z wielu wzajemnie ze sobą powiązanych i przenikających się elementów. Oczywiście prze-

7 Tamże. 
bieg rozwoju kulturowego znacząco różni się od przebiegu rozwoju biologicznego.

Określenie specyfiki rozwoju kulturowego i jego prawidłowości nie jest sprawą łatwą. Wygotski powołuje się między innymi na badania procesu zapamiętywania Bineta ${ }^{8}$, w których porównywano specyfikę oraz przebieg tego procesu u osób dysponujących znakomitymi możliwościami szybkiego zapamiętanie wyznaczonej liczby cyfr z osobami niedysponującymi takimi umiejętnościami. W cytowanych badaniach, zauważa L. S. Wygotski, zapomniano, że czym innym są możliwości zapamiętywania, a czym innym sama technika zapamiętywania. Ukazane w danych badaniach zjawisko określono jako symulację pamięci. Wnioskowano, że większość operacji psychicznych można symulować, tzn. zastąpić innymi, które są do nich podobne/ /zbliżone, z uwagi na cechy zewnętrzne, choć zróżnicowane ze względu na ich istotę. Wytrenowaną technikę zapamiętywania ujęto jako pamięć sztuczną, a eksperymenty mające na celu kształtowanie pamięci sztucznej i trenowanie technik zapamiętywania przeważnie polegały na zastąpieniu pamięci cyfr pamięcią słowną. Chodzi o to, że każdej cyfrze przyporządkowano konkretną literę. Ciągi cyfr zamieniano więc na słowa, słowa na zdania, a zdania łączono w określone teksty. Oczywiście dany przykład wskazuje na możliwości zastąpienia jednych operacji psychicznych innymi, ale nie pozwala mówić o symulacji naturalnego rozwoju pamięci. Podkreśla jedynie, że istnieje możliwość zastąpienia jednych operacji psychicznych innymi, zbliżonymi wewnętrznie, że można jedne zasymulować innymi. A mówiąc inaczej, wprowadzić nieprawdę i iluzję do badania zjawisk związanych z pamięcią i zapamiętywaniem, zarówno oszustwo zewnętrzne, jak i wewnętrzne. Przedstawiona bowiem sytuacja przypomina występ iluzjonisty, który wykonuje różne sztuczki, w prawdziwość których wierzą widzowie i je widzą, ale przecież pokazane sztuczki są nieprawdziwe i niemożliwe do wykonania bez sprytu i oszustwa. Opisane eksperymenty trenowania pamięci i kształtowania technik zapamiętywania pozwoliły - zdaniem L. S. Wygotskiego - ich autorowi, przedstawić propozycję, aby w szkołach wprowadzić specjalne lekcje nie tylko z liczenia w pamięci, ale też trenujące techniki zapamiętywania. Pominęli

8 Tamże. 
jednak postulat wprowadzenia zajęć ze sztuki zapamiętywania, a nie techniki zapamiętywania9.

Ponadto L. S. Wygotski zauważa, że ujęcie opisanego wariantu rozwoju kulturowego w kategoriach fikcji, tzn. włączającego element fikcji jako swoistego oszustwa naturalnego rozwoju organizmu i jednocześnie wywołującego przejście do bardziej złożonych zachowań, nie tłumaczy jego istoty, przede wszystkim z tego powodu, że zapomina się, iż rozwój kulturowy jest rozwojem realnym, podlegającym swoistym zasadom rozwojowym, a nie rozwojem fikcyjnym. Rozwój ów warunkowany jest nie tylko determinantami biologicznym, ale również społecznymi. Oznacza to, że podlega także zasadom konwergencji uwzględniającej determinanty biologiczne i społeczne. Dziecko bowiem, zależnie od wieku, jest w stanie opanować mniej lub bardziej złożone zachowania kulturowe. Innymi słowy, wewnętrzna gotowość, dojrzałość organizmu sprawia, że dziecko jest przygotowane do opanowania określonych zachowań kulturowych, ale będzie mogło to uczynić wtedy, kiedy uzyska stymulację do nabycia danego zachowania ze strony środowiska społecznego. I tak, w określonym wieku dziecko nabywa umiejętność mówienia, a w innym wieku liczenia ${ }^{10}$.

Relacje między wewnętrznymi i zewnętrznymi determinantami rozwoju kulturowego, podkreśla L. S. Wygotski, są zróżnicowane. Oczywiste jest, że gotowość biologiczna pozwala na opanowanie zachowań istniejących w środowisku społeczno-kulturowym, jednak owa gotowość biologiczna jest raczej warunkiem, a nie stricte stymulatorem rozwoju kulturowego dziecka, dlatego że struktura nabywania zachowań kulturowych jest stymulowana czynnikami zewnętrznymi. Większość badań zrealizowanych w celu wyjaśnienia mechanizmów nabywania zachowań kulturowych jednostronnie tłumaczyła dane mechanizmy. Na przykład badania wyjaśniające zależność między dojrzewaniem biologicznym a rozwojem mowy u dziecka. Mniej jest jednak badań wskazujących zależność między rozwojem mowy a rozwojem myślenia. A przecież każde zachowanie kulturowe jest w istocie zachowaniem społecznym.

9 Tamże.

10 Tamże. 
Dziecko opanowujące np. język angielski i dziecko opanowujące język jakiegoś prymitywnego plemienia, zależnie od środowiska, w którym zachodzi dany proces, opanowuje zupełnie różne sposoby myślenia. Mówi się o tym, że istnieją różne sfery rozwoju człowieka, dla których środowisko jest determinantem podstawowym. I właśnie rozwój kulturowy jest najlepszym przykładem na potwierdzenie tej tezy, gdyż jest zdominowany wpływami zewnętrznymi. Jest też de facto egzorozwojem i jednocześnie wymierną socjokulturowego dojrzewania dziecka.

Ważnym zagadnieniem $\mathrm{w}$ badaniu rozwoju kulturowego dziecka jest wskazanie psychogenezy zachowań kulturowych. Wygotski powołuje się na własne badania eksperymentalne, w czasie których udało się wyodrębnić cztery stadia rozwoju kulturowego, wzajemnie ze sobą powiązane i po sobie następujące. Scalone dają możliwość poznania istoty rozwoju dowolnej funkcji psychicznej ${ }^{11}$.

Stadium pierwsze, za L. S. Wygotskim, można nazwać stadium zachowań prymitywnych i prymitywnej psychiki. Charakteryzuje się tym, że małe dziecko zapamiętuje to, co obserwuje, bazując na pamięci wewnętrznej, biologicznej. To ile zapamięta i jaka jest jakość i trwałość zapamiętywania zależy od jego indywidualnej uwagi, indywidualnej pamięci i zainteresowania obserwowanym. Na ogół trudności, których doświadcza dziecko $\mathrm{w}$ obserwowaniu oraz zapamiętywaniu obserwowanego, są stymulatorem pozwalającym na przejście do kolejnego stadium rozwoju kulturowego oraz rozwoju funkcji psychicznych. Przeważnie dziecko w pełni samodzielnie i mechanicznie stara się kierować procesem zapamiętywania. W warunkach eksperymentalnych zapamiętywanie przez dziecko określonych elementów (rzeczy, zjawisk, sytuacji, ludzi) polegało na tym, że zapamiętywało ono, mobilizując własny potencjał, swoją naturalną pamięć lub uzyskując wsparcie, jeśli nie radziło sobie z zadaniem, ze strony osób dorosłych. $\mathrm{Na}$ przykład przed dzieckiem znajdowały się rozłożone konkretne obrazki. Zatem dziecko słyszało wypowiadane konkretne słowo, nazwę któregoś obrazka, i jednocześnie spoglądało na dany obrazek lub wskazywało ruchem, gdzie to słowo jest przedstawione ${ }^{12}$.

\footnotetext{
11 Tamże.

12 Tamże.
} 
Zazwyczaj dziecko bardzo szybko opanowuje konkretny sposób zapamiętywania, który został mu zasugerowany przez otoczenie, ale nie potrafi pojąć, w jaki sposób obrazki pomogły mu przypomnieć sobie słowo. Przykład: przed dzieckiem ponownie rozkłada się obrazki i wypowiada słowa, ale nie te, które przedstawiają obrazki. Dziecko wskazuje obrazek i wypowiada słowo przedstawione na nim, a nie to, które słyszy. Opisana sytuacja obrazuje kolejne stadium w rozwoju pamięci i zachowań kulturowych u dziecka nazwane przez L. S. Wygotskiego stadium naiwnej psychiki. Nazwa ta jest adekwatna do istniejącego określenia naiwnej fizyki (jest rozumiane jako naiwny sposób wykorzystania przez małpy i małe dzieci narzędzi wspierających pracę ludzką i ludzkie działania). Naiwność owa charakteryzuje się tym, że relatywnie do wieku, dotychczasowych doświadczeń oraz własnych potrzeb dziecko stara się operować różnymi przedmiotami, którymi posługują się dorośli ludzie. Jednak dotychczasowe doświadczenia i chęć zaspokojenia własnej potrzeby nie wystarczają, by właściwie wykorzystać taką pomoc i przeważnie doprowadzają do porażki. W opisanej wyżej sytuacji eksperymentalnej dziecko zorientowało się, że obrazki mogą pomóc w zapamiętywaniu słów. Jednak charakterystyczna dla danego stadium naiwna psychika i niewielkie doświadczenie nie pozwalają mu w pełni wykorzystywać obrazków do ich zapamiętywania. Zachowanie i myślenie dziecka w danym stadium jest tożsame z zachowaniem i myśleniem człowieka pierwotnego. Charakteryzuje się tym, że sposób myślenia zależy od rzeczy, z którą osoba ma styczność. U człowieka pierwotnego przedmiot/ /rzecz determinował/determinowała myśl. U dziecka myśl determinuje rzecz. W przypadku człowieka pierwotnego przyczyną takiego zachowania był brak wiedzy na temat otoczenia. U dziecka wynika ono z braku znajomości własnych możliwości psychicznych. Stadium drugie jest stadium przechodnim. Zazwyczaj dziecko dość szybko przechodzi do kolejnego stadium, które można określić jako stadium zachowań kulturowych warunkowanych wpływem zewnętrznym. Doświadczenie oraz poziom rozwoju psychicznego, szczególnie wykorzystanie znanych sytuacji i zachowań do przeniesienia ich na sytuacje i zachowania nieznane, pozwalają dziecku na wykonanie określonych zadań poprawnie. Na przykład przed dzieckiem znajdują się rozłożone obrazki. Dziecko, słysząc wypowiadane słowo, stara 
się wskazać obrazek w największym stopniu zbliżony do słyszanego słowa $^{13}$.

Trzecie stadium rozwoju psychicznego oraz rozwoju kulturowego dziecka, podobnie jak drugie, trwa stosunkowo krótko i jest zastępowane kolejnym - czwartym stadium, cechującym się tym, że zachowanie dziecka jest motywowane i konstruowane determinantami zewnętrznymi oraz znakami wykorzystywanymi do motywowania i konstruowania tych zachowań; przechodzi w warunkowanie wewnętrzne. Motywator/aktywator zewnętrzny „wrasta” w dziecko i staje się motywatorem/aktywatorem wewnętrznym. Przykład: dziecko stara się zapamiętać określone słowa w takiej kolejności, w jakiej rozłożone są obrazki. Po kilkakrotnym powtórzeniu danego ćwiczenia nie potrzebuje już powielania identycznego sposobu rozłożenia obrazków, by wskazać spośród nich ten, którego nazwę słyszy wypowiadaną przez dorosłego. Stadium czwarte charakteryzuje się też i tym, że znak zewnętrzny staje się mobilizatorem wewnętrznych potencjałów dziecka, to stadium interioryzacji zachowań kulturowych i kulturowego myślenia ${ }^{14}$.

Istnieją cztery sposoby przejścia do analizowanego stadium. Lew S. Wygotski omawia dwa z nich. Pierwszy nazywa „wrastaniem na zasadzie szwa" - szew łączy scalane elementy tkaniny, dając w rezultacie określoną całość. Oznacza to, że z punktu widzenia tkaniny jako całości jest elementem nieistotnym. Identycznie jest ze znakiem, który jest wykorzystywany do kształtowania określonych zachowań i umiejętności u dziecka. Dany przebieg drogi rozwojowej ilustruje zachowanie dziecka, kiedy ma ono do czynienia z dość trudnymi sytuacjami wyboru, a określone znaki, np. obrazki, towarzyszące tej sytuacji są łączone z określonym zachowaniem. Lew S. Wygotski podkreśla, że w czasie dość skomplikowanej sytuacji wyboru u dziecka w pierwszej kolejności między znakiem/stymulatorem a jego reakcją pojawiają się nazwy lub asocjacje jako elementy pośrednie. W czasie ćwiczenia danej umiejętności lub zachowania te elementy pośrednie automatyzują się, zlewając w całość, przechodzą w reakcję sensoryczną, a zatem

\footnotetext{
13 Tamże.

14 Tamże.
} 
motoryczną. Identyczne dane uzyskał także W. M. Wundt ${ }^{15}$, który zasugerował, że wiele reakcji i zachowań, poprzez ich ćwiczenie, a zatem automatyzację, w czasie ich przebiegu mogą być identyfikowane z czasem przebiegu odruchów bezwarunkowych ${ }^{16}$.

Kolejnym możliwym sposobem przejścia ze stadium trzeciego do czwartego, lub inaczej „wrastania” motywatora/aktywatora zewnętrznego w wewnętrzny, jest sposób, który ilustruje następujący przykład: dziecko opanowuje określoną reakcję lub określone zachowanie za pomocą znaku zewnętrznego w swoisty dla siebie sposób na tyle automatycznie, że staje się ona/ono reakcją/zachowaniem warunkowaną/ /warunkowanym wewnętrznie. Zatem stykając się z innymi sytuacjami dotychczas nieznanymi, uruchamia swoje wspomnienia, których używa jako znak, aby poradzić sobie z ich realizacją.

Opisany przez L. S. Wygotskiego schemat rozwoju kulturowego potwierdzają konkretne przykłady. Pierwszy z nich obejmuje rozwój umiejętności arytmetycznych. Stadium pierwsze dotyczy wykorzystywania przez dziecko naturalnych arytmetycznych reakcji do momentu, kiedy nauczy się liczyć. Wśród tych naturalnych reakcji arytmetycznych znajdują się: percepcja ilości, porównywanie mniejszych i większych grup przedmiotów, ogólna percepcja liczby elementów tworzących określoną grupę przedmiotów, klasyfikowanie przedmiotów na grupy i inne. W następnym stadium („naiwnej psychologii”) dziecko liczy, naśladując dorosłych, ale nie ma świadomości, w jaki sposób można liczyć, korzystając z cyfr. Znakomity przykład zachowania dziecka w danym stadium, zdaniem L. S. Wygotskiego, przytacza W. Stern ${ }^{17}-$ dziewczynka poproszona o policzenie palców badacza odpowiedziała, że potrafi policzyć wyłącznie własne palce. Stadium trzecie charakteryzuje umiejętność liczenia na palcach, a czwarte - liczenie w pamięci, kiedy palce do liczenia są już niepotrzebne ${ }^{18}$.

15 W. M. Wundt, Grundzüge der physiologischen Psychologie, W. Engelmann, Leipzig 1874.

16 Tamże.

17 W. Stern, Psychologie der frühen Kindheit bis zum sechsten Lebensjahr, Quelle \& Meyer, Leipzing 1914.

18 L. S. Wygotski, dz. cyt., s. 191-207. 
Identycznie, zauważa L. S. Wygotski, można podzielić rozwój pamięci dziecka. Trzy typy pamięci: mechaniczna, skojarzeniowa i logiczna, odpowiadają określonym okresom rozwojowym człowieka przedszkolnemu, szkolnemu i dorosłości - oraz są adekwatne do stadium pierwszego, trzeciego oraz czwartego. Oznacza to, że pamięć logiczna jest „wrośniętą” do wnętrza pamięcią skojarzeniową ${ }^{19}$.

Podany wyżej wniosek pozwala zasugerować, że wszystkie, nawet złożone zachowania, reakcje i funkcje psychiczne można wyjaśnić, stosując analizę historyczno-kulturową. Na przykład pamięć słowna, tzn. zapamiętywanie za pomocą znaczeń znajdujących się w konkretnych słowach, ich desygnatów jest pamięcią skojarzeniową. Słowa bowiem w pamięci ludzkiej występują w dwojakiej postaci - jako znaczące elementy po prostu obecne w pamięci i jako znaki umożliwiające zapamiętywanie.

Ważne znaczenie, sugeruje L. S. Wygotski, w rozwoju kulturowym dziecka ma rozwój mowy i myślenia, które również można przedstawić, korzystając ze stadiów podanych powyżej. Co prawda, wielu psychologów, zdaniem L. S. Wygotskiego, traktuje rozwój mowy i rozwój myślenia rozdzielnie, tzn. tak, że jeden jawi się jako zewnętrzny wyraziciel drugiego. Inni z kolei łączą je, definiując myśl jako mowę pozbawioną dźwięku. Jednak historia rozwoju kulturowego dowodzi, że mowa i myślenie mają zupełnie odmienne źródła, a dodatkowo badania naukowe nad onto- i filogenezą rozwoju mowy i myślenia wskazują, że do określonego momentu ich rozwój przebiega samodzielnie, odmiennymi drogami. Krzyk oraz głużenie dziecka należą do form zachowania, które nie mają wymiaru reakcji intelektualnych. Tożsamy w intelektualnych zachowaniach małego dziecka i małp jest brak zależności pomiędzy mową i myśleniem. Myślenie instrumentalne poprzedza więc powstanie i rozwój mowy. Jednak w pewnym momencie drogi rozwoju mowy i myślenia zachodzą na siebie wzajemnie. Dziecko odkrywa wówczas instrumentalną funkcję słów, tzn. to, że każda rzecz ma swoją nazwę/swoje imię. Zaczyna pytać o nazwy wszystkiego, co widzi, obserwuje otoczenie, poszerzając tym samym zasób słownikowy. Innym ważnym momentem w rozwoju mowy i myślenia jest przej-

19 Tamże. 
ście mowy zewnętrznej w mowę wewnętrzna. Badania J. Piageta ${ }^{20}$, podkreśla L. S. Wygotski, dają odpowiedź, kiedy następuje ten moment. Piaget ${ }^{21}$ sugeruje bowiem, że mowa staje się mową wewnętrzną w wymiarze psychologicznym wcześniej niż w wymiarze fizjologicznym. Egocentryczna mowa dziecka (tzn. dla siebie samego) jest mową wewnętrzną w wymiarze psychologicznym i zewnętrzną w kwestii formy. Jest też etapem przejściowym między mową zewnętrzną a mową wewnętrzną. W okresie podejmowania przez dziecko edukacji szkolnej przejawy mowy egocentrycznej praktycznie nie występują. I w tym też momencie mowa zewnętrzna przekształca się w mowę wewnętrzną. Można więc sądzić, że opisana charakterystyka rozwoju mowy wpisuje się w stadia rozwoju kulturowego dziecka, podane powyżej, tzn. w stadium prymitywizmu odpowiada etap przedjęzykowy, zatem odkrycie przez dziecko roli słowa mieści się w stadium trzecim, a egocentryzm słowny dziecka i przejście od mowy zewnętrznej do mowy wewnętrznej stanowią elementy przejścia ze stadium trzeciego do czwartego ${ }^{22}$.

Specyfika rozwoju kulturowego dziecka dyktuje konieczność doboru równie specyficznej metody badań tegoż rozwoju. L. S. Wygotski proponuje, aby metodę taką nazwać instrumentalną, o ile zachowania kulturowe zasadniczo są właśnie zachowaniami instrumentalnymi. Dodaje także, że naukowy opis procesu badawczego jest opisem funkcjonalnym, a istota badań jest ujmowana w kategorii badań jakościowych. Opis funkcjonalny wynika z tego, że rozwój zachowań dziecka odbywa się za pomocą dwóch grup stymulatorów, przy czym każda $\mathrm{z}$ tych grup ma odmienne funkcjonalne znaczenie dla zachowania osoby ludzkiej. Wykonanie przez dziecko określonego zadania wymaga zastosowania określonych stymulatorów i/lub określonego stymulatora, tzn. zastosowania ich/jego jako środka pomocniczego w celu realizacji takiej lub innej czynności psychicznej. Istnieją też podstawy, by sądzić, że stworzenie i wykorzystanie określonych znaków jako środków pomocniczych dla wykonania określonego zadania, które ma do wykonania dziecko, z psychologicznego punktu widzenia ma identycz-

\footnotetext{
20 J. Piaget, Le Langage et la pensée chez l'enfant, Delachaux and Niestle, Neuchâtel, Paris 1923.

21 Tamże.

22 L. S. Wygotski, dz. cyt., s. 191-207.
} 
ną strukturę jak wynalezienie i zastosowanie przez człowieka narzędzi wspomagających jego pracę. W procesie badawczym stosuje się obserwację i analizę badanych problemów w płaszczyźnie bodziec-reakcja, należy również uwzględnić dwojakie znaczenie/dwojaką funkcję pełnioną przez stymulator/stymulatory w wywoływaniu, kształtowaniu, regulacji oraz modyfikacji zachowania dziecka. Stymulator bowiem może pełnić funkcję obiektu, na który jest ukierunkowane zachowanie dziecka, aby zrealizować określone zadanie przed nim stawiane (np. zapamiętać, porównać, wybrać, ocenić, nazwać itd.) lub rolę środka, za pomocą którego dziecko uruchamia określone mechanizmy psychologiczne, aby owo zadanie zrealizować (np. zapamiętywanie, wybór, porównanie). W przedstawionych przykładach relacje funkcjonalne między zachowaniem a stymulatorem zachowania są odmienne. W tych dwóch sytuacjach relacje funkcjonalne na kontinuum zachowanie-stymulator zachowania w charakterystyczny dla siebie sposób definiuje, warunkuje i organizuje zachowanie dziecka. Specyfika badania zachowania dziecka polega więc na obecności stymulatorów z jednej oraz drugiej grupy równocześnie, a więc stymulatorów, które mają odmienne jakościowo i funkcjonalnie znaczenie. Teza, która przyświeca badaniu zachowań dziecka, postuluje, że opanowuje ono swoje zachowania na identycznych zasadach oraz w identyczny sposób jak przyswaja sobie otaczające je środowisko zewnętrzne. Inaczej człowiek opanowuje siebie samego w identyczny sposób jak opanowuje siły przyrody, ale czyni to za pomocą określonego systemu znaków/ /symboli wypracowanych przez ludzkość, znaków/symboli, które można nazwać kulturowymi. Stąd metodę badania zachowania dziecka można określić jako historyczno-genetyczną, gdyż wprowadza do badań historyczny punkt widzenia. Zachowanie ludzi może więc być zrozumiane wyłącznie przy zastosowaniu analizy historycznej rozwoju ludzkich zachowań23.

Zastosowanie sugerowanej metody badań, zdaniem L. S. Wygotskiego, jest możliwe w poznaniu następujących zagadnień: a) analiza kulturowej budowy sposobów zachowania się ludzi; b) analiza struktury zachowań kulturowych jako całości i jako całości funkcjonalnej, złożonej z określonych elementów, tzn. wszystkich procesów tworzących

23 Tamże. 
zachowanie; c) psychogeneza kulturowego zachowania dziecka. Dana metoda jest kluczem nie tylko do poznania bardziej skomplikowanych zachowań kulturowych, ale również wskazuje drogi opanowania tych zachowań przez dziecko w czasie jego wychowania i nauczania ${ }^{24}$.

Wskazana metoda uwzględnia zarówno założenia własne, adekwatne wyłącznie do tej metody, jak i założenia przyjęte w badaniu zachowań determinowanych odruchami bezwarunkowymi. Jej istota polega na poznaniu złożonej struktury zachowań kulturowych oraz ich wielorako warunkowanej specyfiki. Obiektywizm metody natomiast warunkuje zastosowanie sugerowanych wyżej elementów metody eksperymentalnej, której celem jest poznanie biologicznych uwarunkowań zachowania ludzi. W czasie badania złożonych zachowań kulturowych, składających się z równie złożonych procesów i reakcji wewnętrznych, omawiana metoda pozwala w warunkach eksperymentalnych spowodować powstanie złożonych zachowań kulturowych, zamiast badać już obecne i utrwalone zachowanie kulturowe - przy czym najbardziej znaczące poznawczo jest trzecie stadium rozwoju zachowań kulturowych. Poprzez łączenie złożonych procesów wewnętrznych z działaniami zewnętrznymi, np. kiedy proponujemy dziecku zapamiętanie nazw obrazków lub pogrupowanie figur geometrycznych, tworzy się obiektywne warunki dla różnorodnych reakcji powiązanych funkcjonalnie z reakcjami wewnętrznymi, a to warunkuje obiektywizm realizowanych badań. Badacz, obrazowo rzecz ujmując, zachowuje się tak jak badacz, który chce określić szlak wędrówki ryby od momentu, kiedy ryba zanurkowała w wodę, do momentu, kiedy z wody wypłynie na jej powierzchnię. Aby to poznać, zawiązuje na rybie sznurek i śledząc ruch końca sznurka, który trzyma w ręce, stara się fiksować krzywą drogi, jaką przemierza ryba. W badaniach zachowań kulturowych realizowanych omawianą metodą podejmowane są próby utrzymywania sznurka, stanowiącego atrybut zewnętrzny, od wpływu uwarunkowań wewnętrznych ${ }^{25}$.

Podsumowując poglądy L. S. Wygotskiego na temat rozwoju zachowań kulturowych, należy zauważyć, że autor nie tylko podkreśla złożoność strukturalną i jakościową tych zachowań, ale również nie

\footnotetext{
24 Tamże.

25 Tamże.
} 
mniej zróżnicowane ich warunkowanie wewnętrzne i zewnętrzne oraz historyczno-kulturowe odpowiadające za powstawanie, rozwój, utrwalanie modyfikację oraz nabywanie zachowań kulturowych, w tym też zachowań kulturowych swoistych konkretnej osobie ludzkiej.

\section{Summary}

Child's cultural Development in the Concept of L. S. Vygotsky

The text of the article presents and describes the views of the eminent psychologist L. S. Vygotsky on the child's cultural development. Not only does it indicate the sources and determinants of cultural development, but also the stages of the child's acquisition of the cultural development. In addition, the views signalled by L. S. Vygotsky's research on the possibility of acquiring the child's acquisition of cultural behaviour and cultural thinking from the point held by the child's own abilities and the impact of his closest social environment. 